\title{
THE IMPACT OF TEACHER PROFESSIONAL DIARY ON THEIR REFLECTIVE, COMMUNICATIVE AND PROFESSIONAL SKILLS
}

\author{
Eka Tkavashvili \\ Ilia State University, Georgia \\ E-mail: eka_tkavashvili@iliauni.edu.ge
}

\begin{abstract}
Teacher professional diaries are teacher reflections on their own and their colleagues'observed practice. They are effective tools of increasing teacher qualification. Few research studies worldwide, while no such research studies in Georgia have been conducted on the impact of the application of reflective diaries on teachers' reflective, communicative, and professional skills. Therefore, the aim of the research was to find out whether teachers' reflective, communicative, and professional skills developed as a result of the application of reflective diaries, and if so, to what degree they increased. Quantitative research (an experiment with participation of 62 teachers) was held, with an experimental group whose participants wrote reflective diaries for 9 weeks and a control group which did not undergo any special treatment. A 5-point Likert scale questionnaire was developed, and its reliability and validity were assessed. Preexperimental and post-experimental self-assessment questionnaire was held, the results were assessed and compared through descriptive statistics and a T-test. The results revealed that there was a positive average relationship between the application of diaries and reflective thinking, communicative and professional skills. According to the study results, the application of teacher reflective diary can be recommended as an effective tool for the development of reflective thinking, communication, and professional qualification. Keywords: communicative skills, professional skills; reflection diary, reflective thinking skills
\end{abstract}

\section{Introduction}

\section{Significance}

According to Chong and Cheah (2009), "competent effective teachers help to build a strong system of education" (p.1), such as in Singapore, second most successful in the world country concerning general education (OECD, 2018). The quality of a teacher's qualification, in turn, depends on teacher knowledge, skills, and values (Chong \& Cheah, 2009). Gore et al. (2017). Antoniou et al. (2015) stated that teacher professional development had a significant positive impact on the quality of teaching. Research by Göker (2016), Hilton et al. (2013), Insuasty and Zambrano Castillo (2010), as well as Ukrop et al. (2019) confirmed that teacher professional diaries were effective tools for teacher professional development. Göker (2016) held a quantitative and qualitative (survey and interview) concerning teacher diaries. In Hilton et al. (2013) study teacher diary was used as one of research tools. The participant teachers approved of its application, as confirmed by one more research tool - questionnaire. Based on research findings, he recommended to introduce diary writing into teacher training programs. Insuasty and Zambrano Castillo (2010) studied the efficiency of teacher journals through journals, blogs, metaphors, conferences, and a questionnaire. Dincel and Savur (2018) in a qualitative study found that holding a reflective diary helped teachers to enhance their writing abilities, professional skills and personal development. 
PROBLEMS

OF EDUCATION IN THE $21^{\text {st }}$ CENTURY Vol. 79, No. 2, 2021

274

While there are numerous studies of teacher and teacher-student diary writing role in good teaching in general (as shown above), there are fewer studies dealing with the impact of teacher diary application on separate skills such as reflection, communication, and professional skills. Klimova (2015) in her literature analysis claimed that teacher diaries developed their reflection capacity. Patterson (2014) analyzed his experience of organizing a teacher diary writing program with teacher-to-be and found many benefits of its application: developing writing skills, self-confidence and (if held in groups) organization skills. Taqi et al. (2015) investigated through a questionnaire the impact of journal writing on the ability to communicate in writing and came to conclusion that communication skills were effectively developed through teacher diary writing. The narrative-based inquiry by Aharonian (2016) and the critical analysis, observations, and interview by Chien (2018) found that reflective writing increased teachers' professional knowledge and skills. Lopera Medina (2013) held a case study on the application of English teachers'-to-be diary in order to analyze the development of their reading skills. The study found it useful for the development of reading skills.

None of the above-discussed research studies were experimental. No scholarly / empirical research on the issue of teacher reflective diary writing in Georgia has been conducted. Only one descriptive article by Gogoladze (2019) is available on the Internet, which explains what reflection is and gives teachers' practical recommendations on holding it but does not provide any empirical data. Therefore, the current research tries to fill this gap.

\section{Teacher Professional Diaries / Journals}

Reflection helps practitioners to feel confident and competent about the matters, which involve both personal and professional growth. A process of learning enhances their confidence when confronted with complex and emotionally demanding situations in the workplace. Oelofsen (2012) emphasized that teachers may gain from reflecting despite the fact that reflection is timeconsuming, while professionals have such a busy schedule (Oelofsen, 2012).

Merely reflecting on the experience does not ensure that a teacher will identify the real causes of the problem or recognize the elements of successful teaching. 'Critical reflection' refers to an activity or process in which an experience is recalled, considered, and evaluated, usually in relation to a broader purpose. It is a response to past experience and involves conscious recall and examination of the experience as a basis for evaluation and decision-making, and as a source for planning and action. Reflective practice is "learning through and from experience towards gaining new insights of self and practice" (Finlay, 2008, p.1).

Reflection is more productive when concrete experience is documented in written form. This considerably improves the quality of reflection and provides a valuable source for further reference (Tsingos-Lucas et al., 2017). The essence of reflective diaries is to facilitate the process of reflection by guiding a teacher through self-talk.

A diary / journal is a sequential, dated chronicle of events and ideas, which includes the personal responses and reflections of the writer (or writers) on those events and ideas. A journal has six defining attributes: it is written, dated, informal, flexible, private, and archival. "Reflection is the path both to self-knowledge and to greater personal efficacy. Although there are many ways to reflect, the journal is concrete evidence of one's evolving thought processes, documenting valuable, often fleeting glimpses of understanding" (Stevens \& Cooper, 2009, p. $3)$.

Spadling and Wilson (2002) believed that reflective writing can promote reflective thinking. They mentioned the following benefits of journal writing: (1) journals serve as a permanent record of thoughts and experiences; (2) journals provide a means of establishing and maintaining relationship with instructors; (3) journals serve as a safe outlet for personal concerns and frustrations; (4) journals are an aid to internal dialogue; 5) journals serve as windows into 
students' thinking and learning; 6) journals provide a means of establishing and maintaining relationship with students; and 7) journals serve as dialogical teaching tools (p. 1396).

Reflective journaling can be used at university level and for in-service teacher professional education programs with a variety of purposes in focus. The efficacy of the usefulness of reflective journals was explored while teaching writing to university students who reflected on the instructional practices with an aim of evaluating the effectiveness of teaching (Ahmed, 2019).

Reflective diaries may be of particular importance for student and novice teachers. Diaries guide the student / novice teachers to improve their professional skills through reflection on teacher training sessions. In addition, diaries are appreciated and used by experienced university teachers from various faculties and school teachers. According to Ukrop et al. (2019), it is a "container for writing that provides students with a framework to structure their thoughts and reflections" (p.2).

Reflective diaries are applicable for ensuring foreign language teacher development. Reflective teaching, while applying them, is divided into four phases: 1. identification of the problem, 2. observation and analysis, 3. re-generalization, and 4. actual verification. The data gained through observation by means of questionnaires, recordings, interviews, etc. are critically analyzed in reflective journals. After reflecting on their philosophy, practice, beliefs, values, attitude and affection, teachers analyze the causes of the problem and learn from others' experience. Through cyclic reflection, teachers become effective reflectors (Liu \& Zhang, 2014).

\section{Research Problem}

Judging by students' results (OECD, 2018), teachers in many countries (including Georgia) do not demonstrate optimistic results in skill level. To increase the level of teachers' skills, as shown in the literature review above, teacher reflective diaries are an effective tool.

This research is trying to fill the gap and to study how the application of teacher diary changes three aspects of teachers' qualification (reflective thinking, communicative and professional skills). The impact of reflective diary application on teacher reflective thinking, communicative and professional skills has been recently investigated to a certain degree in various countries: in Czech Republic by Klimova (2015), in Japan by Patterson (2014), in Israel by Aharoyan (2016), in Taiwan by Chien (2018), and by some other researchers in various countries. However, a wider-scale / experimental investigation is needed to make far-going conclusions. In Georgia there are no studies on the issue, so the author of the current article was especially interested whether in Georgia teacher reflective diaries could be used for increasing the level of teacher reflective, communicative, and professional skills.

\section{Research Focus}

Reflective diaries written by teachers can benefit them in many ways. Di Pardo LéonHenri (2021) enumerated the following benefits of teacher diaries:

- building understanding about themselves and their students;

- becoming a reflective professional and developing their cognitive and metacognitive skills;

- $\quad$ improving observational and critical analysis skills;

- stimulating reflective thinking skills;

- developing cooperation (with the help of dialogue diaries);

- $\quad$ enhancing professional development;

- $\quad$ promoting teacher autonomy;

- helping to make decisions. 
Eka TKAVASHVILI. The impact of teacher professional diary on their reflective, communicative and professional skills

PROBLEMS

OF EDUCATION

IN THE $21^{\text {st }}$ CENTURY

Vol. 79, No. 2, 2021

276

This research concentrated on reflective thinking skills (first 4 items on the list), communication with colleagues $\left(5^{\text {th }}\right.$ item $)$, and professional skills $\left(2^{\text {nd }}\right.$ and $6^{\text {th }}$ items $)$, therefore, it covered the majority of the benefits of teacher reflective diaries.

\section{Research Aim and Questions}

The aim of the research was to find out whether teachers' reflective, communicative, and professional skills developed as a result of the application of reflective diaries, and if so, to what degree they increased.

The research questions, correspondingly, were as follows:

- Do teachers' reflective thinking skills increase as a result of the application of teacher reflection diary?

- If so, to what degree do they increase?

- Do teachers' communicative skills increase as a result of the application of teacher reflection diary?

- If so, to what degree do they increase?

- Do teachers' professional skills increase as a result of the application of teacher reflection diary?

- If so, to what degree do they increase?

\section{Hypotheses}

Null, positive and negative hypotheses were formulated:

$\mathrm{H}_{0 \mathrm{a}}$ : There is no impact of professional diary writing on reflective thinking skills.

$\mathrm{H}_{1 \mathrm{a}}$ : There is a positive impact of professional diary writing on reflective thinking skills.

$\mathrm{H}_{22}$ : There is a negative impact of professional diary writing on reflective thinking skills.

$\mathrm{H}_{0 b}$ : There is no impact of professional diary writing on communicative skills.

$\mathrm{H}_{1 \mathrm{~b}}$ : There is a positive impact of professional diary writing on communicative skills.

$\mathrm{H}_{2 b}$ : There is a negative impact of professional diary writing on communicative skills.

$\mathrm{H}_{0 \mathrm{c}}$ There is no impact of professional diary writing on professional skills.

$\mathrm{H}_{1 \mathrm{c}}$ : There is a positive impact of professional diary writing on professional skills.

$\mathrm{H}_{2 \mathrm{c}}$ : There is a negative impact of professional diary writing on professional skills.

\section{Research Methodology}

\section{General Background}

The scientific view, philosophy of Positivism/Realism and an empirical-analytic paradigm constitute the research approach of this study (Cohen et al, 2018). They imply that a quantitative (experimental) research design was used for this research as a basis for finding out the impact of conducting a reflective diary on teachers' reflection, communication, and professional skills in Georgian context. This design was chosen, as Cohen et al. (2018) stated that quantitative (especially, experimental) research design yields objective (permits statistical treatment, correspondingly, enables generalization), valid and reliable results.

The current research was part of a larger study including defining teacher attitudes to reflective diary writing in Georgia as its first stage (Tkavashvili, 2021) and then holding an experiment with teachers from several schools to support the idea that the application of reflective diaries can be an effective tool for the improvement of teacher skills. In the first (survey) study 1046 teachers from all regions of Georgia, including private and public schools, participated, a sample representative of the population - Georgian school teachers. The scale 
of the second study was more modest (62 teachers), as this was an experiment, not a survey. Besides the analysis of experimental data, a qualitative analysis of teacher diary entries will follow in a further publication, to provide triangulation and thus to increase the trustworthiness of the obtained results.

The theoretical framework of the current research was Kolb's (1984) Experiential Learning Theory and Schön's (1983) Reflective Teaching Theory. According to Kolb's theory, both teachers and students learn by experience and then turn it into knowledge, while, according to Schön, professional practice requires the ability to reflect over it. These ideas, in turn, were based on John Dewey's (1993) hands-on activities ideas.

The research design included the following stages:

- Developing the pre-experimental and post-experimental questionnaire and its piloting (January 2020);

- Sample selection (February 2020);

- Holding the pre-experimental questionnaire (February 2020);

- Holding intervention in the experimental group and ordinary / traditional work in the control group (9 weeks) (February-April 2020)

- Holding the post-experimental questionnaire (May 2020);

- Analysis of obtained results (May 2020).

\section{Sample Selection}

Teachers from across Georgia were shortly informed online (https://www.facebook.com/ groups/138750106331227/, https://www.facebook.com/ETAG-in-Georgia-152713621457305, and https://www.facebook.com/search/top?q=Teachers\%20of\%20Georgia) about teacher diaries, their goals, types, advantages, and challenges. They were shown some sample diary entries. To make it more comprehensible for them, the information and the questionnaire were in Georgian. All teachers who would volunteer, were invited to participate in the study. Besides, some participants were recruited through the project ERASMUS+ (Assessment Tools for New Learning Environments in Higher Education Institutions. 2017-2020, \# ASSET 585587-EPP1-2017-1-IL-EPPKA2-CBIHE-JP) and the conference within the project entitled The First Online Academic Writing Conference IFAW. The researcher also presented the current study at various teachers' meetings throughout Georgia during 2019/2020 educational year and informed them that the questionnaire was available electronically or they could address the researcher personally to get a copy.

After this they (also online) answered a pre-experimental self-assessment questionnaire, according to which the level of their reflective thinking, communicative and professional skills was defined.

\section{Table 1}

\section{Participants' Demographic Data}

\begin{tabular}{|c|c|c|}
\hline School / group & $\begin{array}{l}\text { Control group: totally } 14 \text { schools; } 31 \\
\text { teachers }\end{array}$ & $\begin{array}{l}\text { Experimental group: } 15 \text { schools, } 31 \\
\text { teachers }\end{array}$ \\
\hline Private schools & 1 school, 4 teachers & 3 schools; 4 teachers \\
\hline Public School & 13 schools, 27 teachers & 12 schools: 27 teachers \\
\hline Tbilisi schools & 8 schools; 21 teachers & 11 schools: 21 teachers \\
\hline Regional schools & 7 schools from 5 regions & 7 schools from 5 regions \\
\hline \multirow[t]{2}{*}{ Teacher gender } & M & M \\
\hline & 30 & 31 \\
\hline $\begin{array}{l}\text { Teaching } \\
\text { experience }\end{array}$ & $\begin{array}{l}1-5 \text { years }-5 ; 6-10 \text { years }-4 ; 11-20-13 \text {; } \\
\text { above } 20-9\end{array}$ & $\begin{array}{l}1-5 \text { years }-5 ; 6-10 \text { years }-6 ; 11-20 \text { years }- \\
15 ; \text { above } 20-5\end{array}$ \\
\hline
\end{tabular}


PROBLEMS

OF EDUCATION IN THE $21^{\text {st }}$ CENTURY Vol. 79, No. 2, 2021

278

The population of the study was 64,000 school teachers in Georgia, according to Geostat. ge (2020)). The only way to reach them during the pandemic and lockdown was via social media, and teachers were quite reluctant to be involved in any study. Although the total number of volunteers (62) obviously does not allow to speak about a representative sample, they come from totally 16 schools: 11 schools in the capital and seven schools from six (out of 12) regions in Georgia, three private and 13 public schools. Teachers from all major types of schools and geographic distribution were involved. The teaching experience of the teachers ranged from 1-5 years to over 20 years, and all groups according to experience were represented in both groups quite similarly. Therefore, the application of cluster and stratificational approach lets the researcher generalize the results for the Georgian context.

\section{Procedure}

Those 31 teachers who volunteered to conduct the diaries and did so for 9 weeks (three weeks a dialogue diary with the trainer, three weeks a dialogue with a colleague at their choice, and three weeks an individual diary) were the 'experimental group' (inverted commas are used as they never came together as a group, but underwent the same treatment), while the rest of the respondents (also 31 teachers) did teaching the way they have always done (the control group). While the experimental group were writing dialogue diaries with the trainer, they better understood how to write it. While writing dialogue diaries with colleagues, they continued to improve their entries/analyses, benefitting from sharing with each other. Eventually, they were able to write really good diary entries.

After that period the teachers had to answer a post-experimental questionnaire questions. The questions for the control group were identical to the pre-experimental group questions, while the experimental group teachers had to answer, besides those, several additional questions concerning their experience of diary-writing.

\section{Data Collection}

Data resulted from a questionnaire were made up by the researcher. As already mentioned, the questionnaire was mostly held online, as during the pandemic this was the most convenient form as well as this was the fastest way to reach more participants. However, some (quite few) participants preferred to hand the questionnaires in personally. The dialogue diaries were held online, individual diaries were mostly held online. Some teachers preferred to hold them onpaper and then scan for the researcher.

The majority of items had to be assessed by the respondents in a 5-point Likert scale), while one item in the post-experimental questionnaire for the experimental group was openended, which enabled the respondents to express their opinion of the treatment they had undergone.

The tool was developed based on several existing inventories: the reflective thinking skills part on Karpov (2003) and Mirzaei et al. (2913), while the communicative and professional skills part based on Good and Mulryan (1990). However, as the questions were modified and applied partially and were translated into Georgian, the native language of the respondents, for providing the face, construct, and content validity of the questionnaire it was assessed by three experts in the field. Their recommendations were taken into consideration (some items were added, omitted, or reformulated). Also, in order to ensure the reliability of the questionnaire items and the questionnaire on the whole, the test-retest approach was applied to provide the reliability of the test. The results are shown in Table A1 in the Appendix. The answers to the items marked by asterisks (*) were calculated in reverse order (answer " 1 " as " "5, "2" as "4", "3" as " 3 ", "4" as " 2 ", and "5" as " 1 "), as they are negative by nature. This remark concerns 
the following tables as well. To formulate some items positively while others negatively was necessary to provide that the respondents assess the items attentively, not mechanically (such as all "5-"s) (Croasmun \& Ostrom, 2011). They were warned about it. For statistics reversed calculation was applied, as the researcher needed to 'average mean results' in order to see the treatment effect on the whole. While assessing the obtained mean results, the results below 2.67 were viewed as negative, from 2.67 to 3.33 as marginal, and 3.34 and above as positive (Joshi et al, 2015; Lipsey et al., 2012).

It is seen from Table A1 in the Appendix, most answers in the 'retest' are the same (see part 1 items 2, 5, 9, part 2 items 3 and 10, part 3 items 1 and 7) or almost the same (the remaining items). The correlation of the two measurements was found to be very high (1.00 or, more exactly, .997), and the significance $p=.000<.001$, which means that the questionnaire was reliable.

\section{Research Results}

The obtained data were first entered to Excel sheets and then statistically treated with SPSS 26 software. For brevity, the items are not repeated in the following tables, but they are the same as above. The results (rounded to $100^{\text {th }}$ ) are presented in Tables 2-5 below. The 'overall mean' in the table stands for the mean result for all items in the part, while the 'total mean' stands for the mean result of the whole questionnaire.

\section{Table 2}

\section{Experimental Group Pre-Experimental Results}

\begin{tabular}{|c|c|c|c|c|c|c|}
\hline Items & $M$ & $M d n$ & Mode & $S D$ & Skewness & Kurtosis \\
\hline \multicolumn{7}{|c|}{ Part 1: Reflective thinking skills } \\
\hline 1 & 4.39 & 4.00 & 4.00 & .56 & -.14 & -.85 \\
\hline $2^{*}$ & 4.16 & 4.00 & 4.00 & .90 & -1.52 & 3.76 \\
\hline 3 & 4.23 & 4.00 & 4.00 & .67 & -1.01 & 2.87 \\
\hline 4 & 4.10 & 4.00 & 4.00 & .75 & -0.16 & -1.12 \\
\hline 5 & 4.13 & 4.00 & 4.00 & .72 & -.78 & 1.35 \\
\hline 6 & 4.35 & 4.00 & 4.00 & .61 & -.35 & -.57 \\
\hline 7 & 4.26 & 4.00 & 5.00 & .89 & -1.15 & .78 \\
\hline 8 & 4.61 & 5.00 & 5.00 & .50 & -.49 & -1.89 \\
\hline 9 & 4.39 & 4.00 & 4.00 & .62 & -.46 & -.56 \\
\hline 10 & 4.00 & 4.00 & 4.00 & 1.13 & -1.20 & .69 \\
\hline $11^{*}$ & 4.06 & 4.00 & 4.00 & .63 & -.04 & -.26 \\
\hline $12^{*}$ & 4.00 & 4.00 & 4.00 & .78 & .00 & -1.29 \\
\hline 13 & 4.32 & 4.00 & 4.00 & .65 & -.44 & -.61 \\
\hline Part 1 overall mean & 4.25 & & & & & \\
\hline \multicolumn{7}{|c|}{ Part 2: Communicative skills } \\
\hline 1 & 3.90 & 4.00 & 4.00 & .94 & -.82 & 1.30 \\
\hline $2^{*}$ & 3.19 & 3.00 & 4.00 & 1.22 & -.40 & -.64 \\
\hline 3 & 4.26 & 4.00 & 4.00 & .51 & .35 & -.23 \\
\hline $4^{*}$ & 3.74 & 4.00 & 4.00 & 1.29 & -.98 & -.04 \\
\hline $5^{*}$ & 3.61 & 4.00 & 4.00 & 1.26 & -.81 & -.21 \\
\hline
\end{tabular}


Eka TKAVASHVILI. The impact of teacher professional diary on their reflective, communicative and professional skills

PROBLEMS

OF EDUCATION IN THE $21^{\text {st }}$ CENTURY Vol. 79 , No. 2, 2021

\begin{tabular}{lllllll}
\hline 6 & 3.39 & 4.00 & 4.00 & .50 & .49 & -1.89 \\
\hline 7 & 4.32 & 4.00 & 4.00 & .83 & -2.17 & 7.55 \\
\hline 8 & 3.77 & 4.00 & 4.00 & 1.15 & -1.23 & 1.34 \\
\hline $9^{*}$ & 4.48 & 5.00 & 5.00 & .85 & -1.85 & 3.10 \\
\hline 10 & 3.55 & 4.00 & 4.00 & 1.09 & -.46 & -.48 \\
\hline Part 2 overall mean & 3.82 & & & & & \\
\hline & & Part 3: Professional skills & & \\
\hline 1 & 3.93 & 4.00 & 4.00 & .73 & -2.12 & 8.56 \\
\hline 2 & 4.19 & 4.00 & 4.00 & .75 & -.85 & 1.06 \\
\hline 3 & 4.16 & 4.00 & 4.00 & .69 & -.22 & -.77 \\
\hline 4 & 4.10 & 4.00 & 4.00 & .54 & .10 & .70 \\
\hline 5 & 4.32 & 4.00 & 4.00 & .70 & -1.17 & 2.56 \\
\hline 6 & 4.35 & 4.00 & 4.00 & .61 & -.35 & -.57 \\
\hline 7 & 4.13 & 4.00 & 4.00 & .85 & -.96 & .83 \\
\hline 8 & 4.16 & 4.00 & 4.00 & .73 & -.81 & 1.18 \\
\hline $9^{*}$ & 4.55 & 5.00 & 5.00 & .57 & -.78 & -.36 \\
\hline $10^{*}$ & 4.52 & 5.00 & 5.00 & .81 & -2.06 & 4.38 \\
\hline $11^{*}$ & 4.55 & 5.00 & 5.00 & .85 & -2.08 & 3.82 \\
\hline $12^{*}$ & 4.65 & 5.00 & 5.00 & .55 & -1.27 & .76 \\
\hline $13^{*}$ & 4.68 & 5.00 & 5.00 & .54 & -1.46 & 1.36 \\
\hline $14^{*}$ & 3.84 & 4.00 & 4.00 & 1.07 & -.71 & -.66 \\
\hline $15^{*}$ & 4.19 & 4.00 & 5.00 & .91 & -.98 & .26 \\
\hline Part 3 overall mean & 4.29 & & & & & \\
\hline Total mean & 4.15 & & & & & \\
\hline & & & & & & \\
\hline & & & & & \\
\hline
\end{tabular}

The mean, median and mode were close to each other, which makes the obtained means quite trustworthy. The majority of the mean results in the experimental group were close $(3.39<M<3.90)$, equal to or more than 4 , which reveals that on the whole the respondents quite positively assessed their reflective thinking, communicative and professional skills. Only one mean result was low $(M=3.19)$. The standard deviations ranged from average $(S D=0.50)$ to high $(S D=1.29)$. This means that the respondents' opinions on many items were not homogeneous.

Skewness was mostly negative and above -3 . This reveals that there were more results that are lower than the mean result. Therefore, in reality many results were to a certain degree lower than the mean. There were some items, whose kurtosis was more than +1 . This means that the distribution of assessments to these items was too high and the distribution is not normal. These were item 1 and 2 in part one, items 1,8 and especially 7, in part 2 they were items 1 , 7 , and 9 , while in part 3 these were items $2,8,13$, and especially 1 and 10 . The items whose kurtosis was less than -1 reveal more unity of opinion. These were items 4,8 , and 1 in part 1 , item 6 for part 2, and there were no such items for part 3. The experimental group teachers assessed their professional skills the highest $(M=4.29)$, then reflective thinking $(M=4.25)$ and the lowest, still positive enough their communicative skills $(M=3.82)$. The total mean equaled 4.15 , which is quite positive. 
Table 3

Control Group Pre-Experimental Results

\begin{tabular}{|c|c|c|c|c|c|c|}
\hline & $M$ & $M d n$ & Mode & $S D$ & Skewness & Kurtosis \\
\hline \multicolumn{7}{|c|}{ Part 1: Reflective thinking skills } \\
\hline 1 & 4.29 & 4.00 & 4.00 & 0.64 & -0.59 & -0.34 \\
\hline $2^{*}$ & 3.84 & 4.00 & 4.00 & 0.97 & 1.43 & -1.06 \\
\hline 3 & 4.26 & 4.00 & 4.00 & 0.51 & -0.23 & 0.35 \\
\hline 4 & 4.10 & 4.00 & 4.00 & 0.83 & -1.53 & -0.19 \\
\hline 5 & 4.45 & 4.00 & 4.00 & 0.51 & -2.09 & 0.20 \\
\hline 6 & 4.30 & 4.00 & 4.00 & 0.66 & -1.24 & 0.92 \\
\hline 7 & 3.42 & 4.00 & 4.00 & 1.06 & 1.06 & -1.13 \\
\hline 8 & 4.65 & 5.00 & 5.00 & 0.49 & -1.71 & -0.64 \\
\hline 9 & 4.42 & 4.00 & 5.00 & 0.62 & -0.51 & -0.57 \\
\hline 10 & 3.71 & 4.00 & 4.00 & 1.13 & -0.47 & -0.56 \\
\hline $11^{*}$ & 4.10 & 4.00 & 4.00 & 0.79 & 1.65 & -1.06 \\
\hline $12^{*}$ & 4.06 & 4.00 & 4.00 & 0.95 & .331 & -0.94 \\
\hline 13 & 4.29 & 4.00 & 4.00 & 0.46 & -1.13 & 0.97 \\
\hline Part 1 overall mean & 4.15 & & & & & \\
\hline \multicolumn{7}{|c|}{ Part 2: Communicative skills } \\
\hline 1 & 4.06 & 4.00 & 4.00 & 1.73 & -1.01 & -0.10 \\
\hline $2^{*}$ & 3.68 & 4.00 & 3.00 & 0.94 & -0.89 & -0.04 \\
\hline 3 & 4.39 & 4.00 & 4.00 & 0.50 & -1.89 & 0.49 \\
\hline $4^{*}$ & 4.26 & 4.00 & 4.00 & 0.73 & -0.94 & -0.45 \\
\hline $5^{*}$ & 3.97 & 4.00 & 4.00 & 1.02 & -0.42 & -0.75 \\
\hline 6 & 4.42 & 4.00 & 4.00 & 0.50 & -2.02 & 0.34 \\
\hline 7 & 4.29 & 4.00 & 4.00 & 0.64 & 3.95 & -1.15 \\
\hline 8 & 4.19 & 5.00 & 5.00 & 1.08 & -0.13 & -1.10 \\
\hline $9^{*}$ & 4.19 & 5.00 & 5.00 & 1.08 & -0.13 & -1.10 \\
\hline 10 & 3.61 & 4.00 & 4.00 & 1.20 & -0.95 & -0.41 \\
\hline Part 2 overall mean & 4.10 & & & & & \\
\hline \multicolumn{7}{|c|}{ Part 3: Professional skills } \\
\hline 1 & 4.16 & 4.00 & 4.00 & 0.58 & 0.00 & -0.01 \\
\hline 2 & 4.29 & 4.00 & 4.00 & 0.46 & -1.13 & 0.97 \\
\hline 3 & 4.19 & 4.00 & 4.00 & 0.79 & 1.07 & -2.09 \\
\hline 4 & 4.23 & 4.00 & 4.00 & 0.56 & -0.103 & 0.50 \\
\hline 5 & 4.35 & 5.00 & 5.00 & 0.80 & 1.08 & -1.17 \\
\hline 6 & 4.39 & 4.00 & 5.00 & 0.66 & -0.55 & -0.64 \\
\hline 7 & 4.10 & 4.00 & 4.00 & 0.91 & 3.93 & -1.63 \\
\hline 8 & 3.97 & 4.500 & 5.00 & 0.92 & 1.96 & -1.53 \\
\hline $9^{*}$ & 4.30 & 5.00 & 5.00 & 0.57 & -0.78 & -0.36 \\
\hline $10^{*}$ & 4.43 & 5.00 & 5.00 & 0.86 & 1.02 & -2.41 \\
\hline $11^{*}$ & 4.35 & 4.00 & 5.00 & 0.75 & 1.73 & -1.21 \\
\hline
\end{tabular}


Eka TKAVASHVILI. The impact of teacher professional diary on their reflective, communicative and professional skills

PROBLEMS

OF EDUCATION IN THE $21^{\text {st }}$ CENTURY Vol. 79 , No. 2, 2021

\begin{tabular}{lllllll}
\hline $12^{*}$ & 4.52 & 5.00 & 5.00 & 0.68 & 1.81 & -1.79 \\
\hline $13^{*}$ & 4.58 & 5.00 & 5.00 & 0.67 & 1.89 & -2.07 \\
\hline $14^{*}$ & 3.90 & 4.00 & 4.00 & 1.16 & 0.06 & -1.02 \\
\hline $15^{*}$ & 4.32 & 4.00 & 5.00 & 0.70 & -1.75 & -0.55 \\
\hline Part 3 overall mean & 4.31 & & & & & \\
\hline Total mean & 4.09 & & & & & \\
\hline
\end{tabular}

The mean, median and mode were close to each other, which makes the obtained means quite trustworthy. Similarly to the experimental group, the majority of the mean results in the control group were close to $(3.61<M<3.97)$, equal or more than 4 , which reveals that on the whole the respondents quite positively assessed their reflective thinking, communicative and professional skills. One result was quite low $(M=3.42)$ however, this result can also be viewed as positive. The standard deviations ranged from average $(S D=0.50)$ to high $(S D=1.73)$. This means that the respondents' views were not too homogeneous. The skewness was mostly negative and above -3 . This reveals that there were more results that were lower than the mean result. Therefore, in reality many of their results were to a certain degree lower than the mean. There was a perspective to improve them. There were no items whose kurtosis was more than +1 . This reveals that the assessments were more or less homogeneous. The kurtosis of items 2 and 7 in part 1, items 7,8 , and 9 in part 2 , and of items $3,5,7,8,10,11,12,13$, and 14 were less than -1 . This means that the opinions of different respondents on these items were rather similar to each other. The control group teachers assessed their professional skills the highest $(M=4.31)$, then reflective thinking $(M=4.15)$ and the lowest, but still positively their communicative skills $(M=4.10)$. The total mean equaled 4.09 , which is quite positive.

The overall means of both groups were close enough to each other, so the groups were quite comparable.

Table 4

Experimental Group Post-Experimental Results

\begin{tabular}{lllllll}
\hline & $M$ & Mdn & Mode & SD & Skewness & Kurtosis \\
\hline Part 1: Reflective thinking skills & & & & & & \\
\hline 1 & 4.42 & 5.00 & 5.00 & 1.12 & 4.74 & -2.30 \\
\hline $2^{*}$ & 4.26 & 4.00 & 4.00 & 0.73 & 1.69 & -1.00 \\
\hline 3 & 4.58 & 5.00 & 5.00 & 0.50 & -2.02 & -0.34 \\
\hline 4 & 4.58 & 5.00 & 5.00 & 0.56 & -0.08 & -0.93 \\
\hline 5 & 4.58 & 5.00 & 5.00 & 0.76 & 3.60 & -1.96 \\
\hline 6 & 4.48 & 5.00 & 5.00 & 0.89 & 7.01 & -2.38 \\
\hline 7 & 4.35 & 4.00 & 4.00 & 0.66 & -0.60 & -0.53 \\
\hline 8 & 4.77 & 5.00 & 5.00 & 0.43 & -0.11 & -1.38 \\
\hline 9 & 4.48 & 5.00 & 5.00 & 0.68 & -0.15 & -0.97 \\
\hline 10 & 4.00 & 4.00 & 5.00 & 1.00 & -.637 & -.641 \\
\hline $11^{*}$ & 4.06 & 4.00 & 4.00 & 0.63 & -0.04 & -0.26 \\
\hline $12^{*}$ & 4.00 & 4.00 & 4.00 & 0.78 & 0.00 & -1.29 \\
\hline 13 & 4.48 & 5.00 & 5.00 & 0.93 & 7.03 & -2.51 \\
\hline Part 1 overall mean & 4.39 & & & & & \\
\hline Part 2 Com & & & & &
\end{tabular}

Part 2: Communicative skills 


\begin{tabular}{|c|c|c|c|c|c|c|}
\hline 1 & 4.03 & 4.00 & 4.00 & 0.91 & 0.40 & -0.91 \\
\hline $2^{*}$ & 3.87 & 4.00 & 4.00 & 0.99 & -0.52 & -0.60 \\
\hline 3 & 4.58 & 5.00 & 5.00 & 0.56 & -.077 & -.933 \\
\hline $4^{*}$ & 4.06 & 5.00 & 5.00 & 1.31 & 0.96 & -1.44 \\
\hline $5^{*}$ & 3.68 & 4.00 & 5.00 & 1.33 & -0.95 & -0.55 \\
\hline 6 & 4.65 & 5.00 & 5.00 & 0.49 & -1.71 & -0.64 \\
\hline 7 & 4.58 & 5.00 & 5.00 & 0.56 & -0.08 & -0.93 \\
\hline 8 & 3.97 & 4.00 & 4.00 & 0.85 & -0.72 & -0.30 \\
\hline $9^{*}$ & 4.58 & 5.00 & 5.00 & 0.56 & -.077 & -.933 \\
\hline 10 & 4.00 & 4.00 & 4.00 & 0.96 & 0.16 & -0.68 \\
\hline Part 2 overall mean & 4.20 & & & & & \\
\hline \multicolumn{7}{|l|}{ Part 3: Professional skills } \\
\hline 1. & 4.32 & 4.00 & 5.00 & 0.79 & 1.00 & -1.10 \\
\hline 2 & 4.52 & 5.00 & 5.00 & 0.57 & -0.57 & -0.64 \\
\hline 3 & 4.52 & 5.00 & 5.00 & 0.63 & -0.05 & -0.94 \\
\hline 4 & 4.35 & 4.00 & 4.00 & 0.49 & -1.71 & 0.64 \\
\hline 5 & 4.61 & 5.00 & 5.00 & 0.72 & 5.20 & -2.18 \\
\hline 6 & 4.61 & 5.00 & 5.00 & 0.50 & -1.89 & -0.49 \\
\hline 7 & 4.45 & 5.00 & 5.00 & 0.62 & -.40 & -0.69 \\
\hline 8 & 4.10 & 4.00 & 4.00 & 0.91 & 3.07 & -1.34 \\
\hline $9^{*}$ & 4.45 & 5.00 & 5.00 & 0.77 & 2.19 & -1.48 \\
\hline $10^{*}$ & 4.60 & 5.00 & 5.00 & 0.56 & 0.18 & -1.04 \\
\hline $11^{*}$ & 4.43 & 5.00 & 5.00 & 0.86 & 2.64 & -1.71 \\
\hline $12^{*}$ & 4.63 & 5.00 & 5.00 & 0.49 & -1.78 & -0.58 \\
\hline $13^{*}$ & 4.74 & 5.00 & 5.00 & 0.44 & -.70 & -1.16 \\
\hline $14^{*}$ & 4.23 & 4.00 & $4.00 \mathrm{a}$ & 0.80 & .0 .40 & -0.86 \\
\hline $15^{*}$ & 4.16 & 4.00 & 4.00 & 0.82 & 1.41 & -1.09 \\
\hline Part 3 overall mean & 4.41 & & & & & \\
\hline Total mean & 4.36 & & & & & \\
\hline \multicolumn{7}{|l|}{ Part 4: Assessment of experiment results } \\
\hline $\begin{array}{l}1 \text { According to my experience, conducting a reflective } \\
\text { diary is useful. }\end{array}$ & 4.52 & 5.00 & 5.00 & 0.51 & -2.14 & -0.07 \\
\hline
\end{tabular}

PROBLEMS

OF EDUCATION

IN THE $21^{\text {st }}$ CENTURY

Vol. 79, No. 2, 2021

As result of conducting a reflective diary, my following

skills improved:

\begin{tabular}{|c|c|c|c|c|c|c|}
\hline 2. 1. reflective thinking & 4.58 & 5.00 & 5.00 & 0.50 & -2.02 & -0.34 \\
\hline 2. 2. critical thinking & 4.55 & 5.00 & 5.00 & 0.51 & -2.10 & -0.20 \\
\hline 2.3. communication & 4.39 & 4.00 & 5.00 & 0.67 & -0.55 & -0.64 \\
\hline 2.4. self-assessment & 4.70 & 5.00 & 5.00 & 0.47 & -1.24 & -0.92 \\
\hline 2.5. professional writing & 4.42 & 5.00 & 5.00 & 0.72 & 2.82 & -1.42 \\
\hline 2.6. awareness of my teaching style & 4.58 & 5.00 & 5.00 & 0.56 & -.077 & -0.93 \\
\hline 2.7. developing interesting ideas & 4.50 & 4.50 & $4.00 \mathrm{a}$ & 0.51 & -2.15 & 0.00 \\
\hline 2.8. professional skills & 4.48 & 5.00 & 5.00 & 0.57 & -0.72 & -0.51 \\
\hline 2.9. co-operation with colleagues & 4.35 & 4.00 & 4.00 & 0.61 & -0.57 & -0.35 \\
\hline Part 4 overall mean & 4.51 & & & & & \\
\hline
\end{tabular}


Eka TKAVASHVILI. The impact of teacher professional diary on their reflective, communicative and professional skills

PROBLEMS

OF EDUCATION IN THE $21^{\text {st }}$ CENTURY Vol. 79, No. 2, 2021

The mean, median and mode were close to each other, which makes the obtained means quite trustworthy. The majority of the mean results in the experimental group were equal to or more than 4 , only 3 results $(M=3.68, M=3.87$ and $M=3.97)$ were close to 4 (these results are also positive). This reveals that on the whole the respondents quite positively assessed their reflective thinking, communicative and professional skills. Their mean level increased compared to pre-experimental results (see Table 6).

The answers to the additional part assessing the teachers' views on the treatment applied were also all positive $(4.39<M<4.70)$. Therefore, the teachers were satisfied by applying teacher reflective diaries. The skewness was mostly negative and above -3 . This reveals that there were more results that were lower than the mean result. Therefore, in reality many of their results were to a certain degree lower than the mean.

The standard deviations were still from average $(S D=0.43)$ to high $(S D=1.33)$. This means that the respondents' views were still not too homogeneous, however, the standard deviations decreased a little, so there was more unity of opinion compared to the pre-experimental results. There were no items whose kurtosis was more than +1 . This reveals that the assessments were more or less homogeneous. The kurtosis of items 1, 5, 6, 12 and 13 in part 1, item 4 in part 2 , and of items $1,5,8,9,10,11,13$ and 15 were less than -1 . This means that the opinions of different respondents on these items were rather similar to each other (the distribution was close to normal).

On the whole, the post-experimental results of the experimental group were better than the pre-experimental ones. The overall means of all parts were above 4 . The total mean increased from 4.15 to 4.36 . All means of the part 4 (additional questions which cannot be compared to pre-experimental results) were above $4(4.35-4.58$, the overall mean was 4.51$)$, which is a very good achievement.

Table 5

Control Group Post-Experimental Results

\begin{tabular}{|c|c|c|c|c|c|c|}
\hline & $M$ & $M d n$ & Mode & $S D$ & Skewness & Kurtosis \\
\hline \multicolumn{7}{|c|}{ Part 1. Reflective thinking skills } \\
\hline 1 & 3.55 & 4.00 & 3.00 & 0.57 & -0.81 & 0.38 \\
\hline $2^{*}$ & 3.74 & 4.00 & 4.00 & 0.82 & -0.21 & -0.27 \\
\hline 3 & 3.74 & 4.00 & 4.00 & 0.82 & -0.21 & -0.27 \\
\hline 4 & 4.06 & 4.00 & 4.00 & 0.73 & -1.01 & -0.10 \\
\hline 5 & 4.39 & 4.00 & 4.00 & 0.62 & -0.56 & -0.46 \\
\hline 6 & 4.45 & 5.00 & 5.00 & 0.72 & -0.38 & -0.95 \\
\hline 7 & 3.42 & 3.00 & 4.00 & 1.09 & -1.26 & 0.06 \\
\hline 8 & 4.68 & 5.00 & 5.00 & 0.48 & -1.46 & -0.80 \\
\hline 9 & 3.71 & 4.00 & 4.00 & 0.82 & 0.08 & -0.54 \\
\hline 10 & 3.77 & 4.00 & 4.00 & 0.76 & 1.26 & -1.03 \\
\hline $11^{*}$ & 4.10 & 4.00 & 4.00 & 0.79 & 1.65 & -1.06 \\
\hline $12^{*}$ & 4.06 & 4.00 & 4.00 & 0.95 & 0.33 & -0.94 \\
\hline 13 & 3.55 & 4.00 & 4.00 & 0.81 & -0.28 & -.017 \\
\hline Part 1 overall mean & 4.21 & & & & & \\
\hline \multicolumn{7}{|c|}{ Part 2. Communicative skills } \\
\hline 1 & 4.06 & 4.00 & 4.00 & 0.81 & 1.05 & -.0 .92 \\
\hline $2^{*}$ & 3.55 & 4.00 & 4.00 & 1.06 & -1.13 & -0.23 \\
\hline
\end{tabular}




\begin{tabular}{|c|c|c|c|c|c|c|}
\hline 3 & 4.52 & 4.00 & 5.00 & 0.51 & -2.14 & -0.07 \\
\hline $4^{*}$ & 3.93 & 4.50 & 5.00 & 1.39 & -.080 & -1.12 \\
\hline $5^{*}$ & 3.68 & 4.00 & 5.00 & 1.25 & -0.53 & -0.65 \\
\hline 6 & 4.32 & 4.00 & 5.00 & 0.70 & -0.75 & -0.56 \\
\hline 7 & 4.26 & 5.00 & 5.00 & 1.12 & 3.27 & -1.90 \\
\hline 8 & 3.23 & 3.00 & 2.00 & 1.18 & -1.19 & 0.06 \\
\hline $9^{*}$ & 3.87 & 4.00 & 4.00 & 0.72 & 0.41 & -0.38 \\
\hline 10 & 3.32 & 4.00 & 4.00 & 1.11 & 0.43 & -1.01 \\
\hline Part 2 overall mean & 3.87 & & & & & \\
\hline \multicolumn{7}{|c|}{ Part 3: Professional skills } \\
\hline 1 & 3.39 & 3.00 & 4.00 & 0.67 & -0.55 & -0.64 \\
\hline 2 & 3.71 & 4.00 & 4.00 & 0.78 & -0.01 & -0.31 \\
\hline 3 & 3.52 & 4.00 & 4.00 & 0.72 & -0.04 & -1.19 \\
\hline 4 & 4.27 & 4.00 & 4.00 & 0.58 & -0.36 & -0.09 \\
\hline 5 & 4.42 & 4.00 & 4.00 & 0.50 & -2.02 & 0.34 \\
\hline 6 & 3.81 & 4.00 & 4.00 & 0.75 & -0.14 & -0.17 \\
\hline 7 & 3.71 & 4.00 & 4.00 & 0.64 & 0.62 & -0.46 \\
\hline 8 & 3.65 & 4.00 & 4.00 & 1.02 & 1.50 & -1.23 \\
\hline $9^{*}$ & 3.65 & 4.00 & 4.00 & 0.66 & 0.90 & -0.95 \\
\hline $10^{*}$ & 4.48 & 4.00 & 5.00 & 0.57 & -0.72 & -0.51 \\
\hline $11^{*}$ & 4.35 & 4.00 & 4.00 & 0.71 & 2.59 & -1.24 \\
\hline $12^{*}$ & 4.29 & 4.00 & 4.00 & 0.90 & 5.82 & -2.09 \\
\hline $13^{*}$ & 4.52 & 4.00 & 5.00 & 0.68 & 4.81 & -1.79 \\
\hline $14^{*}$ & 3.68 & 4.00 & 4.00 & 0.75 & 0.76 & -0.91 \\
\hline $15^{*}$ & 4.13 & 4.00 & 4.00 & 0.81 & 1.51 & -1.06 \\
\hline Part 3 overall results & 3.97 & & & & & \\
\hline Total mean results & 4.00 & & & & & \\
\hline
\end{tabular}

The mean, median and mode were close to each other, which makes the obtained means quite trustworthy. About half of the mean results in the control group were equal to or more than 4, the majority of the results were positive $(M>3.34)$, only 2 results $(M=3.23$ and $M=3.32)$ can be assessed as marginal (neither clearly positive, nor clearly negative), which reveals that on the whole the respondents quite positively assessed their reflective thinking, communicative and professional skills. The mean level of communicative slightly decreased $(4.10 \leftarrow 3.87)$, of professional skills significantly decreased $(4.31 \leftarrow 3.97)$, while reflective thinking skills slightly increased $(4.15 \rightarrow 4.21)$ (see Table 6 ). The skewness was mostly negative and above -3 , which reveals that there were more results that were lower than the mean result, therefore, in reality many students' results were to a certain degree lower than the mean, and there was a perspective to improve them.

The standard deviations still ranged from average $(S D=0.50)$ to high $(S D=1.39)$, which means that the respondents were not too homogeneous in their assessments. There were no items whose kurtosis was more than +1 , which reveals that the assessments were more or less homogeneous. The kurtosis of items 10 and 11 in part 1, items 4, 7, and 10 in part 2, and of items $3,8,11,12,13$ and 15 were less than -1 , which means that the opinions of different respondents on these items were rather similar to each other. 
Eka TKAVASHVILI. The impact of teacher professional diary on their reflective, communicative and professional skills

PROBLEMS

OF EDUCATION

IN THE $21^{\text {st }}$ CENTURY Vol. 79, No. 2, 2021

On the whole, the post-experimental results of the control group were lower than the preexperimental ones. The total mean decreased from $M=4.31$ to $M=3.96$. This may be explained by the pandemic and the stress of unexpectedly moving to totally online teaching, but, to name the cause, additional research is needed.

In table 6 below, pre-experimental and post-experimental mean results of the experimental and control groups are compared to each other in order to see whether the groups decreased, maintained or increased the level of reflective thinking, communicative and professional skills after the experiment.

Table 6

Comparison of the Experimental and Control Group Pre- and Post-Experimental Results

\begin{tabular}{lcccc}
\hline & \multicolumn{2}{c}{ Experimental group } & \multicolumn{2}{c}{ Control group } \\
\hline & $\begin{array}{l}\text { Pre-experimental } \\
\text { results }\left(M_{\max }=5\right)\end{array}$ & $\begin{array}{c}\text { Post-experimental } \\
\text { results }\left(M_{\max }=5\right)\end{array}$ & $\begin{array}{c}\text { Pre-experimental } \\
\text { results }\left(M_{\max }=5\right)\end{array}$ & $\begin{array}{c}\text { Post-experimental } \\
\text { results }\left(M_{\max }=5\right)\end{array}$ \\
\hline $\begin{array}{l}\text { Reflective thinking } \\
\text { skills }\end{array}$ & 4.25 & 4.39 & 4.15 & 4.21 \\
\hline Communicative skills & 3.82 & 4.20 & 4.10 & 3.87 \\
\hline Professional skills & 4.29 & 4.41 & 4.31 & 3.97 \\
\hline
\end{tabular}

The table reveals that, as assessed by the participants according to a 5-point Likert scale, in the experimental group all three skills increased as result of treatment, while in the control group reflective thinking skills slightly increased, communicative skills experienced a minor decrease and professional skills a notable one. Therefore, the experiment results were successful for the experimental group and not successful for the control group. To see whether the improvements in the experimental group were statistically significant, and whether the changes in the control group were statistically significant, a $t$-test was conducted (Tables 7 and 8).

\section{Table 7}

T-Test for Experimental Group Results

One-Sample Statistics

\begin{tabular}{lcccc}
\hline & $\boldsymbol{N}$ & $\boldsymbol{M}$ & SD & SEM \\
\hline Variable 1 & 3 & 4.12 & .26 & .15 \\
\hline Variable 2 & 3 & 4.33 & .12 & .07 \\
\hline
\end{tabular}

One-Sample test

\begin{tabular}{|c|c|c|c|c|c|c|}
\hline & \multicolumn{6}{|c|}{ Test value $=0$} \\
\hline & \multirow{2}{*}{$T$} & \multirow{2}{*}{$d f$} & \multirow{2}{*}{ Sig. (2-tailed) } & \multirow{2}{*}{$\begin{array}{l}\text { Mean } \\
\text { Difference }\end{array}$} & \multicolumn{2}{|c|}{$95 \% \mathrm{Cl}$ of the difference } \\
\hline & & & & & Lower & Upper \\
\hline Variable 1 & 27.39 & 2 & .000 & 4.12 & 3.47 & 4.77 \\
\hline Variable 2 & 64.76 & 2 & .000 & 4.33 & 4.05 & 4.62 \\
\hline
\end{tabular}


Therefore, at $95 \%$ confidence interval of the difference which is normally applied in educational research (Cohen et al, 2018), the significance $p=.0001<.001$. This result implied that the difference between the pre-experimental and post-experimental results in the experimental group is statistically significant. Thus, the positive hypotheses $\left(\mathrm{H}_{1 \mathrm{a}}, \mathrm{H}_{1 \mathrm{~b}}\right.$, and $\left.\mathrm{H}_{1 \mathrm{c}}\right)$ were confirmed.

\section{Table 8}

T-Test for Control Group Results

One-Sample Statistics

\begin{tabular}{|c|c|c|c|c|c|c|}
\hline & $N$ & & $M$ & $S D$ & \multicolumn{2}{|c|}{ SEM } \\
\hline Variable 1 & 3 & & 4.19 & .11 & \multicolumn{2}{|c|}{.06} \\
\hline Variable 2 & 3 & & 4.02 & .17 & \multicolumn{2}{|c|}{.10} \\
\hline \multicolumn{7}{|c|}{ One-Sample test } \\
\hline & \multicolumn{6}{|c|}{ Test value $=0$} \\
\hline & \multirow{2}{*}{$T$} & \multirow{2}{*}{$d f$} & \multirow{2}{*}{ Sig. (2-tailed) } & \multirow{2}{*}{$\begin{array}{c}\text { Mean } \\
\text { Difference }\end{array}$} & \multicolumn{2}{|c|}{$95 \% \mathrm{Cl}$ of the difference } \\
\hline & & & & & Lower & Upper \\
\hline Variable 1 & 66.11 & 2 & .00 & 4.18667 & 3.9142 & 4.4592 \\
\hline Variable 2 & 38.81 & 2 & .00 & 4.01667 & 3.5826 & 4.4507 \\
\hline
\end{tabular}

Therefore, at $95 \%$ confidence interval of the difference which is normally applied in educational research (Cohen et al, 2018), the significance $p=0.0001<0.05$. This result implied that the difference between the pre-experimental and post-experimental results in the control group is statistically significant.

To find out to what degree was the impact of diary application in the experimental group positive, Person correlation was assessed.

\section{Table 9a}

Pearson Correlation between Reflective Thinking Skills and Diary Writing

\begin{tabular}{cccc}
\hline & & Pre-experimental & Post-experimental \\
\hline \multirow{2}{*}{ Reflective thinking skills } & \multicolumn{1}{c}{1} & 0.73 \\
\cline { 2 - 4 } & Significance (2-tailed) & & 0.05 \\
\cline { 2 - 4 } & $N$ & 13 & 13 \\
\hline$r$ & .73 & 1 \\
\hline & Significance (2-tailed) & 0.005 & 13 \\
\hline
\end{tabular}


Eka TKAVASHVILI. The impact of teacher professional diary on their reflective, communicative and professional skills

PROBLEMS

OF EDUCATION IN THE $21^{\text {st }}$ CENTURY Vol. 79 , No. 2, 2021

Table 9b

Pearson Correlation between Communicative Skills and Diary Writing

\begin{tabular}{cccc}
\hline & & Pre-experimental & Post-experimental \\
\hline \multirow{3}{*}{ Communicative skills } & $r$ & 1 & 0.53 \\
\cline { 2 - 4 } & Significance (2-tailed) & & 0.12 \\
\cline { 2 - 4 } & $N$ & 10 & 10 \\
\hline & $r$ & 0.53 & 1 \\
\hline & Significance (2-tailed) & 0.12 & 10 \\
\hline$N$ & 10 & \\
\hline
\end{tabular}

Table 9c

Pearson Correlation between Professional Skills and Diary Writing

\begin{tabular}{cccc}
\hline & & Pre-experimental & Post-experimental \\
\hline \multirow{3}{*}{ Professional skills } & $r$ & 1 & 0.474 \\
\cline { 2 - 4 } & Significance (2-tailed) & & 0.74 \\
\cline { 2 - 4 } & $N$ & 15 & 15 \\
\hline$r$ & 0.474 & 1 \\
\hline & Significance (2-tailed) & 0.74 & 15 \\
\hline$N$ & 15 & \\
\hline
\end{tabular}

From the Tables 9a, 9b, and 9c it can be concluded that the correlation is positive and average, the highest for reflective thinking skills $(r=0.73)$, followed by communicative skills $(r=0.53)$ and professional skills $(r=0.47)$.

As for the comments that the teachers made in the open-ended question, they mention the following advantages of diary writing:

- it enables to follow the progress of each individual student;

- it has been especially useful during online teaching as anyway we had to collect information about every student;

- it is like additional memory - to keep in mind all achievements, problems, activities, etc.;

- lessons are ephemeral - it's over and that's all, a diary helps to keep it in memory for analysis;

- it is a good tool for self-assessment and self-efficiency; one learns to assess oneself more objectively and thoroughly;

- provides systematic self-observation;

- for teachers who enjoy personal diary writing, it's also enjoyable;

- it motivates the teacher to work better;

- it develops analytic and critical skills;

- it enables the teacher to see her strong and weak points;

- it helps to visualize problems;

- it helps to clarify one's teaching style and strategies;

- it makes planning and teaching more thoughtful;

- it's like a mirror for a teacher;

- the peer dialogue helps to obtain colleagues' feedback; 
- it promotes professional development, a deeper understanding of theoretical

knowledge and its link with teaching practice;

- $\quad$ it develops academic writing quality;

- it improves the quality of teaching.

Six respondents out of 31 mentioned that they would continue diary writing after the research would be over, and one wrote she would write it from time to time. One respondent expressed the idea that for novice teachers writing a diary should be compulsory.

As for challenges connected with diary writing, a couple of teachers mentioned it was time-consuming, and they had to find special time for it. One teacher mentioned she was afraid in the beginning she would not be able to do it, but after a couple of entries it became easy.

\section{Discussion}

Although there are many publications concerning the role of teacher diaries, most of them deal with other than skill development benefits such as enhancing social work (Vinjamuri et al. 2017), teaching English writing (Farrah, 2012), students' self-regulated learning strategies (Al-Rawahi \& Al-Balushi, 2015), etc. Besides, the analysis of the existing studies dealing with reflective diary writing brought the researcher to the conclusion that the majority of the articles involved teacher students, and there was a lack of research dealing with actual teachers. Besides, the available publications are qualitative (interview, observation, case studies) and non-experimental qualitative (survey) ones. The current study tried to at least partially fill the existing gap.

The current study revealed that the participant teachers had a positive attitude towards reflective diary writing. It was also found that there was a positive relationship between diary writing and the development of reflective thinking, communicative and professional skills.

Göker (2016) held a research with 16 teacher certification students at a Turkish university who applied a reflective diary during their 6-month-long teaching practice. He applied surveys and interviews. $91 \%$ of the participants expressed a positive opinion of diary writing. Besides, they described advantages and challenges of diary writing, which also were in line with the current research findings. In the current research all items in the pre-experimental questionnaire were assessed positively by the control group, while only one item was assessed on a marginal level (neither positive, nor negative: $M=3.19$ ). In the post-experimental questionnaire, all teachers in the experimental group assessed the application of teacher diary positively, while in the control group only two items were assessed as marginal $(M=3.23$ and $M=3.32$ ). This comparison reveals that the current results were in line with Göker's (2016) results.

In Insuasty and Castillo (2010) study six teacher students were applying a reflection diary during their six-month practicum in a Colombian university. They held a curriculum action research. "Observational and non-observational techniques were used to collect data. The former were journals, blog group discussions and conferences. The latter were metaphors and questionnaires" (ibid, p. 92). The results revealed that they enriched their understanding of reflective teaching and developed their reflective thinking skills. While describing a teacher before this experience, they mentioned such teacher responsibilities as controlling the students' progress, applying innovations, but none of them mentioned that teachers should be reflective practitioners. After the research was completed, they realized the importance of reflective teaching. In the current research, the teachers from the experimental group, while writing the diaries, had to assess their own and their colleague's practice, which stimulated the development of their reflective skills. If before the experiment they already assessed their reflective skills quite positively $(M=4.25)$, after the experiment the level of their skills increased $(M=4.39)$. Therefore, Insuasty and Castillo (2010) findings are also in compliance with the current research. 
Eka TKAVASHVILI. The impact of teacher professional diary on their reflective, communicative and professional skills

PROBLEMS

OF EDUCATION

IN THE $21^{\text {st }}$ CENTURY

Vol. 79 , No. 2, 2021

290

Bashan and Holsblat (2017) held a qualitative study, analyzing 36 Israeli teacher students' entries in reflective diaries (three years, 12 students a year). The research revealed that reflective diaries supported teacher students' communication with each other, school teachers and their instructor, helped to build mutual trust. Keeping the diaries improved their lesson planning skills. Sharing knowledge and experiences was also emphasized by both practicing teachers and student teachers. In the current research, the teachers communicated with the trainer for the first three weeks, then with their peers for the next three weeks, which significantly increased their communication skills (before the experiment their level was $M=3.82$, while post-experimental level became $M=4.20$ ). The above findings are also in congruence with the current research.

Moghaddam et al. (2020) conducted a mixed-methodology study: a questionnaire administered to 250 Iranian English teachers and an experiment with 60 teachers, in which the experimental group was conducting reflective diaries. The diaries were found to develop cognitive, metacognitive, affective, critical, and practical skills. The teaching (i.e., professional) skills of the experimental group teaching substantially increased. Almusharraf (2020) involved eight Saudi female teachers undergoing an 11-week teaching practicum. They confessed that reflective practice let them develop their own teaching philosophy. In the current study, the teachers had to purposefully use the professional terminology more thoughtfully as well as to apply their theoretical knowledge in practice. This enabled them to significantly increase their professional skills (before the experiment their level was $M=4.29$, while post-experimental level became $M=4.41$ ). The findings by Moghaddam et al. (2020) and Almusharraf (2020) are consistent with the current study findings.

On the whole, the current research found the positive impact of conducting a teacher diary on three skills (reflective, communicative and professional), while the other available research studies deal with one or two benefits of reflective diaries. Besides, it was an experimental research (compared to descriptive research in all studies except Moghaddam et al), which makes its results more scientifically valuable. And, finally, this is the first research in Georgia on the given issue.

\section{Research Limitations and Further Research Directions}

The number of participants of the research was limited, which does not make its findings generalizable, so it would be useful to replicate the research, both in Georgia and other countries. It would also be useful to investigate the impact of teacher reflective journals on students' achievement.

\section{Conclusions}

The conducted research enriched the scarce empirical data on the issue of teacher diary impact on the improvement of their reflective, communicative, and professional/pedagogical skills. It is one of the very few research studies (Moghaddam et al., 2020; Almusharraf, 2020) of a complex nature (covering several skills) held with teachers and not teacher students as participants. It has shown that a reflective diary benefits teachers as well.

The research gave a positive answer to the research questions (whether writing a reflective diary developed teachers' reflective thinking, communicative and professional skills). The impact was found through an experiment and accompanying questionnaire to be positive and average. The strongest impact was shown on reflective thinking skills $(=0.73)$, while the impact on communicative ( 0.53$)$ and professional (0.47) skills was less. The experimental group increased these skills significantly, while in the control group, without any special treatment, reflective thinking skills slightly increased, however, communicative and professional skills decreased. 
According to the study results, the application of teacher reflective diary can be recommended as an effective tool for the development of reflective thinking, communication, and professional qualification. The quality of teaching will increase if teachers, at least periodically, apply reflective diary writing. This, in turn, will help to improve students' knowledge and skills and thus help solve the problem stated in the research.

\section{References}

Aharonian, N. (2016). I thought to myself: What a long way I've come ...: Teacher writing for professional learning. An International Journal of Teachers' Professional Development, 20(2), 213-228. https://doi.org/10.1080/13664530.2016.1138998

Ahmed, A. M. (2019). Students' reflective journaling: An impactful strategy that informs instructional practices in an EFL writing university context in Qatar. Reflective Practice, 20(4), 483-500. https://doi.org/10.1080/14623943.2019.1638246

Almusharraf, A. M. (2020). Student teachers' development of reflective practice concerning teaching philosophy and peer observations. Arab World English Journal, 11(4) 547-564. https://doi.org/10.24093/awej/vol11 no4.35

Al-Rawahi, N., \& Al-Balushi, S. (2015). The effect of reflective science journal writing on students' selfregulated learning strategies. International Journal of Environmental \& Science Education, 10(3), 367-379. https://files.eric.ed.gov/fulltext/EJ1069260.pdf

Antoniou, P., Kyriakides, L., \& Creemers, B. P. M. (2015). The dynamic integrated approach to teacher professional development: Rationale and main characteristics. An International Journal of Teachers' Professional Development, 19(4), 535-552. https://doi.org/10.1080/13664530.2015.1079550

Bashan, B., \& Holsblat, R. (2017). Reflective journals as a research tool: The case of student teachers' development of teamwork. Cogent Education, 4, 1-15. https://doi.org/10.1080/2331186X.2017.1374234

Chien, C. W. (2018). Analysis of six Taiwanese EFL student teachers' professional learning from writing, discussing, and analyzing critical incidents. An International Journal of Teachers' Professional Development, 22(3), 339-354. https://doi.org/10.1080/13664530.2017.1403368

Chong, S., \& Cheah, S. M. (2009). A values, skills, and knowledge framework for initial teacher preparation programmes. Australian Journal of Teacher Education, 34(3), 1-17.

Cohen, L., Manion, L., \& Morrison, K. (Eds.). (2018). Research methods in education. $8^{\text {th }}$ ed. Routledge.

Croasmun, J., \& Ostrom, L. (2011). Using Likert-type scales in the social sciences. Journal of Adult Education, 40(1), 19-22.

Dewey, J. (1993). How we think. A restatement of the relation of reflective thinking to the educative process (revised edition). Heath.

Dincel, B., \& Savur, H. (2018). Diary keeping in writing education. Journal of Education and Training Studies, 7(1). https://doi.org//48-59.10.11114/jets.v7i1.3758

Di Pardo Léon-Henri, D. (2021). 14 reasons teachers should keep a reflective journal. Reflective Teaching Journal. https://reflectiveteachingjournal.com/reasons-teachers-should-keep-a-reflective-journal

Farrah, (2012). Reflective journal writing as an effective technique in the writing process. An- Najah University Journal of Research (Humanities), 26(4), 998-1025.

Finlay, L. (2008). Reflecting on reflective practice. The Open University. Practice-Based Professional Center. http://ncsce.net/wp-content/uploads/2016/10/Finlay-2008-Reflecting-on-reflectivepractice-PBPL-paper-52.pdf

Gogoladze, N. (2019). Refleqsia da sastsavlo protsesi [in Georgian: Reflection and educational process]. https://en.calameo.com/read/0044967375af0ea5e84c8

Göker, S. D. (2016). Use of reflective journals in development of teachers' leadership and teaching skills. Universal Journal of Educational Research, 4(12A), 63-70.

Good, T. L., \& Mulryan, C. (1990). Teacher ratings: A call for teacher control and self-evaluation. In J. Millman \& L. Darling-Hammond (Eds.). The new handbook of teacher evaluation: Assessing: elementary and secondary school teachers (pp. 191- 215). SAGE. 
Eka TKAVASHVILI. The impact of teacher professional diary on their reflective, communicative and professional skills

PROBLEMS

OF EDUCATION IN THE $21^{\text {st }}$ CENTURY Vol. 79 , No. 2, 2021

Gore, J., Lloyd, A., Smith, M., Bowe, J., Ellis, H., \& Lubans, D. (2017). Effects of professional development on the quality of teaching: Results from a randomised controlled trial of Quality Teaching Rounds. Teaching and Teacher Education, 68, 99-113.

Hilton, G., Assunção Flores, M., \& Niklasson, L. (2013). Teacher quality, professionalism, and professional development: Findings from a European project. An International Journal of Teachers' Professional Development, 17(4), 431-447.

Insuasty, E. A., \& Zambrano Castillo, L. C. (2010). Exploring reflective teaching through informed journal keeping and blog group discussion in the teaching practicum. Profile, 12(2), 87-105.

Joshi, A., Kale, S., Chandel, S., \& Pal, D. K. (2015). Likert scale: Explored and explained. British Journal of Applied Science \& Technology, 7(4), 396-403.

Karpov, A. (2003). Refleksivnost kak psikhicheskoye svoistvo i metodika ee diagnostiki [Reflexivity as psychological characteristic and methods of its diagnostic]. Psykhologicheskiy zhurnal, 24(5), 45-57.

Klimova, B. (2015). Diary writing as a tool for students' self-reflection and teacher's feedback in the course of academic writing. Procedia - Social and Behavioral Sciences, 197, 549 - 553.

Kolb, D. A. (1984). Experiential learning experience as a source of learning and development. Prentice Hall.

Lipsey, Puzio, K., Yun, C., Hebert, M., Steinka-Fry, K., Cole, M., Roberts, M., Anthony, K., \& Busick, M. (2012). Translating the statistical representation of the effects of education interventions into more readily interpretable forms. National Center for Special Education Research, Institute of Education Sciences, U.S. Department of Education.

Liu, L., \& Zhang, Y. (2014). Enhancing teachers' professional development through reflective teaching. Theory and Practice in Language Studies, 4(11), 2396-2401. https://doi.org//10.4304/tpls.4.11.2396-2401

Lopera Medina, S. (2013). Diary insights of an EFL reading teacher. Profile: Issues in Teachers' Professional Development, 15(2), 115-126.

Mirzaei, F., Phang, F. A., \& Kashefi, H. (2014). Measuring teachers' reflective thinking skills. Procedia Social and Behavioral Sciences, 141, $640-647$.

Moghaddam, R. G., Davoudi, M., Adel, S. M. R. et al. (2020). Reflective teaching through journal writing: A study on EFL teachers' reflection-for-action, reflection-in-action, and reflection-onaction. English Teaching \& Learning, 44, 277-296.

OECD (2018). PISA 2018 results. https://www.oecd.org/pisa/publications/pisa-2018-results.htm

Oelofsen, N. (2012). Developing reflective practice: A guide for students and practitioners of health and social care. Lantern Publishing.

Patterson, D. (2014). Using writing journals as a means of increasing EFL writing fluency. Proceedings of ICLC 2013: The 5th International Conference on Language \& Communication, 81-91. December 12-13. Bangkok, Thailand.

Schön, D. (1983). The reflective practitioner: How professionals think in action. Temple Smith.

Spalding, E., \& Wilson, A. (2002). Demystifying reflection: A study of pedagogical strategies that encourage reflective journal writing. Teachers College Record, 104(7), 1393-1421.

Stevens, D. D., \& Cooper, J. E. (2009). Journal keeping: How to use reflective writing for learning, teaching, professional insight, and positive change. Stylus Publishing, LLC.

Taqi, H., Akbar, R., Al-Nouh, N., \& Dashti, A. (2015). The effect of diary writing on EFL students' writing and language abilities. British Journal of Education, 3(2), 75-91.

Tkavashvili, E. (2021). Awareness of the significance of reflective diaries for teachers' professional development. International Journal of Sciences: Basic and Applied Research, 55(3). In print.

Tsingos-Lucas, C., Bosnic-Anticevich, S., Schneider, C., \& Smith, L. (2017). Using reflective writing as a predictor of academic success in different assessment formats. American Journal of Pharmaceutical Education, 81(1), article 8. https://doi.org/10.5688/ajpe8118

Ukrop, M., Švábenský, V., \& Nehyba, J. (2019). Reflective diary for professional development of novice teachers. In Proceedings of the 50th ACM technical symposium on computer science education (SIGCSE '19). February 27-March 2. Minneapolis, MN, USA. ACM, New York, NY, USA. https://doi.org/10.1145/3287324.3287448

Vinjamuri, M., Warde, B., \& Kolb, P. (2017). The reflective diary: An experiential tool for enhancing social work students' research learning. Social Work Education, 36(8), 933-945. https://doi.org/10.1080/02615479.2017.1362379 


\section{Appendix}

Table A1. Defining the reliability of the questionnaire items

\begin{tabular}{llc}
\hline Items & $\begin{array}{l}\text { Variable 1: } \\
\text { Means (first } \\
\text { measurement) }\end{array}$ & $\begin{array}{l}\text { Variable 2: } \\
\text { Means (second } \\
\text { measurement) }\end{array}$ \\
\hline Part 1: Reflective thinking skills & 4.27 \\
\hline $\begin{array}{l}\text { 1. When I fail to do something well at the lesson, first of all, I look } \\
\text { for a cause in myself for what I have done wrong. }\end{array}$ & 4.25 \\
\hline $\begin{array}{l}\text { 2*. When I fail to do something well at the lesson, I shift the blame on } \\
\text { the others. }\end{array}$ & 4.50 \\
\hline $\begin{array}{l}\text { 3. When I come across some problem, I try to recollect similar situations } \\
\text { from my experience, which will help me solve it. }\end{array}$ & 4.20 \\
\hline $\begin{array}{l}\text { 4. Prior to the lesson, I think about the difficulty I might encounter during } \\
\text { the lesson. At the end of the lesson, I compare my prediction with the } \\
\text { reality. }\end{array}$
\end{tabular}

5. After each conducted lesson, I analyze whether I have achieved the set 4.16 goal.

6. Communication with my colleague and then analyzing this discussion $4.03 \quad 4.05$ helps me to clarify some professional issue.

7. Writing and then analyzing my writing helps me to clarify some $4.08 \quad 4.07$ professional issue.

8. Judging by the students' behavior, I always try to find out if the students 4.41 liked the lesson or not, which activity they liked, and why, which activity they did not like, and why.

9. I try to put myself in students' place in order to analyze if the lesson 4.02 was useful or not.

10. I always think about the conducted and future lessons even in the 4.11 moments when I am busy or at rest.

$11 *$. I do not like observing my colleagues' lessons, analyzing, evaluating $3.97 \quad 4.00$ and comparing them with my experience.

12*. I do not like when my colleagues observe my lessons and share their 3.87 impressions and recommendations with me, which I analyze and consider in the future.

13. I like reading and analyzing professional articles and books, comparing $\quad 4.00 \quad 3.98$ them with my experience.

\begin{tabular}{lll}
\hline Part 2: Communicative skills & & \\
\hline $\begin{array}{l}\text { 1. I am well versed in professional terminology. } \\
\text { 2*. Sometimes I understand the term, but I cannot explain it to the }\end{array}$ & 3.97 & 3.91 \\
audience. & 3.95 \\
\hline $\begin{array}{l}\text { 3. I can orally express my opinion concisely and clearly (when speaking } \\
\text { with students and colleagues). }\end{array}$ & 4.32 \\
\hline $\begin{array}{l}\text { 4*. I find it difficult to express my opinion in written form concisely and } \\
\text { clearly (with my students and colleagues) }\end{array}$ & 3.96 \\
\hline $\begin{array}{l}\text { 5* I do not like discussing professional issues with my colleagues. } \\
\text { 6. I understand students' arguments and I try to consider them. }\end{array}$ & 3.90 \\
\hline $\begin{array}{l}\text { 7. I do not find it difficult to explain the lesson aims, activity procedures } \\
\text { and assessment principles, etc. to my students. }\end{array}$ & 4.12 & 3.92 \\
\hline
\end{tabular}


Eka TKAVASHVILI. The impact of teacher professional diary on their reflective, communicative and professional skills

PROBLEMS

OF EDUCATION

IN THE $21^{\text {st }}$ CENTURY Vol. 79 , No. 2, 2021

\begin{tabular}{lll}
\hline 8. I do not find it difficult to prepare a professional conference topic. & 3.45 & 3.44 \\
\hline $9^{*}$ I am reluctant to participate in professional meetings/discussions. & 4.03 & 4.06 \\
\hline 10. I do not find it difficult to make an unprepared speech in meetings/ & 3.30 & 3.30
\end{tabular}
discussions on pedagogical topics using theoretical knowledge.

Part 3: Professional skills

1. I try to rely on the most recent achievements in subject methodology $\quad 3.90 \quad 3.90$ and all related disciplines (Pedagogy, Psychology, etc.) and my knowledge while planning the instructional process.

\begin{tabular}{lll}
\hline 2. I always relate theory to practice (experience) at my lessons. & 3.98 & 4.00 \\
\hline 3. I do not find it difficult to plan and conduct a lesson. & 4.12 & 4.14 \\
\hline $\begin{array}{l}\text { 4. I find it easy to present the materials taking into consideration the } \\
\text { students' individual characteristics and I help the learners to get involved } \\
\text { in the instructional process. }\end{array}$ & & 4.04 \\
\hline
\end{tabular}

5. If I do not know the answer to a student's question, I admit it, and I 3.95 promise to explore it and give an answer to them at the next lesson (I do so).

6. In the first place, I evaluate myself, I am critical of myself and then 4.11 towards my students.

7. I think I evaluate students' knowledge objectively. Since I design 4.30 assessment criteria together with my students, my evaluation does not cause protest.

\begin{tabular}{|c|c|c|}
\hline $\begin{array}{l}\text { 8. I rely only on my own opinions and experience while teaching and I } \\
\text { think that is right. }\end{array}$ & 4.25 & 4.27 \\
\hline $\begin{array}{l}\text { 9*. I never plan my own lessons. Instead, I often follow the plans in a } \\
\text { teacher's book. }\end{array}$ & 4.35 & 4.36 \\
\hline 10*. I never (hardly ever) use pair and group work as they cause chaos. & 4.50 & 4.52 \\
\hline $\begin{array}{l}11^{*} \text {. I never (hardly ever) use technical aids/technologies since their } \\
\text { integration into the instructional process will take a lot of time. }\end{array}$ & 4.70 & 4.72 \\
\hline $\begin{array}{l}12^{*} . \text { I do not often consider a student's opinion as I think I know better } \\
\text { what is necessary and useful for my learners. }\end{array}$ & 4.15 & 4.18 \\
\hline $\begin{array}{l}13^{*} \text {. If I do not know the answer to a student's question, I say that it is not } \\
\text { important, or we have no time for talking about it. }\end{array}$ & 4.20 & 4.23 \\
\hline 14*. I often find it difficult to manage discipline at the lesson. & 3.40 & 3.38 \\
\hline $\begin{array}{l}\text { *15. My students are often dissatisfied with my assessment of their } \\
\text { knowledge/skills. }\end{array}$ & 4.70 & 4.73 \\
\hline Pearson correlation & 1 & 1.000 \\
\hline Sig (2-tailed) & & .000 \\
\hline $\mathrm{N}$ & 35 & 34 \\
\hline Pearson correlation & 1.000 & 1 \\
\hline Sig (2-tailed) & .000 & \\
\hline$N$ & 34 & 37 \\
\hline
\end{tabular}


Eka TKAVASHVILI. The impact of teacher professional diary on their reflective, communicative and professional skills

PROBLEMS

OF EDUCATION

IN THE $21^{\text {st }}$ CENTURY

Vol. 79, No. 2, 2021

Received: January 22, 2021

Accepted: April 02, 2021

295

Cite as: Tkavashvili, E. (2021). The impact of teacher professional diary on their reflective, communicative and professional skills. Problems of Education in the 21 $1^{\text {st }}$ Century, 79(2), 273-295. https://doi.org/10.33225/pec/21.79.273

Eka Tkavashvili

Master of Education (M.Ed.), Ilia State University, 3/5 Cholokashvili Avenue, 0162 Tbilisi, Georgia.

E-mail: eka_tkavashvili@iliauni.edu.ge

ORCID: https://orcid.org/0000-0003-4997-4079 